\title{
Translation and adaptation of the Competencias Esenciales en Salud Pública para los recursos humanos en salud ${ }^{1}$
}

\author{
Maria de Lourdes de Almeida² \\ Aida Maris Peres ${ }^{3}$ \\ Maria Manuela Frederico Ferreira ${ }^{4}$ \\ Maria de Fátima Mantovani ${ }^{3}$
}

Objective: to perform the translation and cultural adaptation of the document named Marco Regional de Competencias Esenciales en Salud Pública para los Recursos Humanos en Salud de la Región de las Américas (Regional Framework of Core Competencies in Public Health for Health Human Resources in the Region of Americas) from Spanish to Brazilian Portuguese. Method: a methodological study comprising the following phases: authorization for translation; initial translation; synthesis of translations and consensus; back-translation and formation of an expert committee. Result: in the translation of domain names, there was no difference in $66.7 \%(\mathrm{~N}=$ $4) ;$ in the translation of domain description and competencies there were divergences in $100 \%$ of them $(N=6, N=56)$. A consensus of more than $80 \%$ was obtained in the translation and improvement in the expert committee by the change of words and expressions for approximation of meanings to the Brazilian context. Conclusion: the translated and adapted document has the potential of application in research, and use in the practice of collective/public health care in Brazil.

Descriptors: Translating; Professional Competence; Public Health; Health Management; Health Personnel Management.

\footnotetext{
${ }^{1}$ Paper extracted from Doctoral Dissertation "Competências essenciais de gestores para a saúde píblica/coletiva", presented to Universidade Federal do Paraná, Curitiba, PR, Brazil. Supported by Coordenação de Aperfeiçoamento de Pessoal de Nível Superior (CAPES), Brazil, process \#10.200.14.2 and Fundação Araucária do Paraná, Brazil, process \#794/2014.

2 Doctoral student, Universidade Federal do Paraná, Curitiba, PR, Brasil. Scholarship holder at Coordenação de Aperfeiçoamento de Pessoal de Nível Superior (CAPES), Brazil. Professor, Universidade Estadual do Oeste do Paraná, Foz do Iguaçu, PR, Brazil.

3 PhD, Associate Professor, Universidade Federal do Paraná, Curitiba, PR, Brazil.

${ }^{4} \mathrm{PhD}$, Professor Coordinator, Escola Superior de Enfermagem de Coimbra, Coimbra, Portugal.
}

How to cite this article

Almeida ML, Peres AM, Ferreira MMF, Mantovani MF. Translation and adaptation of the Competencias Esenciales en Salud Pública para los recursos humanos en salud. Rev. Latino-Am. Enfermagem. 2017;25:e2896. [Access Available in: DOI: http://dx.doi.org/10.1590/1518-8345.1684.2896. 


\section{Introduction}

The essential competencies in public health are defined by the knowledge, skills and attitudes for professional practice in public health care $^{(1-2)}$ that are relevant for decision-making and resolution of population's health problems effectively and efficiently. They refer to the competencies all health professionals working in public health must possess, regardless of the practice scenario in which they develop their activities $^{(2-3)}$.

The Regional Core Competency Framework for Public Health (MRCESP - Marco Regional de Competências Essenciais em Saúde Pública) can be an instrument to characterize public health knowledge, skills and attitudes. The document is a response to the challenges identified by the region of Americas to facilitate training of excellence, collaborate and give consistency to the public/collective health workforce of health systems ${ }^{(2-3)}$. The fundamental strategy of this proposal is based on the following fundamental axes: construction of the MRCESP and measurement of competencies; planning of regional and national capacitation, among other initiatives such as the virtual field of public health ${ }^{(2-3)}$. The MRCESP complements other core strategies of the Pan American Health Organization (PAHO), the World Health Organization and the United Nations, such as Primary Health Care, Essential Public Health Functions (EPHF), and the Development Goals of the Millennium(2-3).

The construction of the MRCESP was based on the meetings organized between 2005 and 2008 by the PAHO's Human Resources for Health Project. Each country was designated for the elaboration of a domain. Brazil was responsible for the first domain, Peru for the second, Puerto Rico for the third, Colombia for the fourth, Chile for the fifth, and Mexico for the sixth domain. These meetings converged on the importance of training focused on development of human resources for public health in the Region of Americas for the consolidation of plans of training and continuous updating, and the need to define essential competencies with performanceoriented approach in health work ${ }^{(2)}$.

Thus, the MRCESP is a support proposal for countries strengthening their public health systems. It is constituted by 56 essential competencies distributed in six domains: nine competencies are of the Análisis de situacion de salud domain (Health situation analysis); 14 of the Vigilancia y control de riesgos $y$ danos domain (Surveillance and control of risks and threats); ten competencies of the Promoción de la salud y participación social domain (Health promotion and social participation); seven of the Políticas, planificación, regulación y control domain (Policy, planning, regulation and control); Eight of the Equidad en el accesso, $y$ calidad en los servicios individuales y colectivos domain (Equitable access, and quality of individual and public health services); and eight in the field of the Salud internacional y salud global (International and global health) $)^{(2-3)}$. These domains were elaborated from the EPHF, an instrument defined by PAHO that describes competency trends and the actions required by health systems in order to address the central objective of public health ${ }^{(2-3)}$.

In the search for professionals prepared for the predominant health care model reality in Brazil and its epidemiological context, the importance of studies in the area of development of health human resources stands out. They point to new work models based on new ways of management and teaching in order to adjust to changes in the health care model(4). To this end, the adoption of the MRCESP reference may contribute to the construction of instruments that help in the development of professionals. This view justifies the translation and adaptation of this document to the Brazilian context.

Given the exposed, the objective of this study was to translate into Brazilian Portuguese and adapt to the Brazilian context the essential competencies for public health professionals suggested by the Pan American Health Organization, as described in the document Marco Regional de competencias esenciales en salud pública para los recursos humanos en salud de la región de las Américas (Regional Framework of Core Competencies in Public Health for Health Human Resources in the Region of Americas).

\section{Methodology}

This is a methodological study for translation and cross-cultural adaptation of the essential public health competencies suggested by PAHO for human resources in health, which followed international recommendations(5-6). Translation and cross-cultural adaptation followed the phases: 1. Authorization of the lead author and PAHO for translation; 2. Initial translation; 3. Synthesis of translations and consensus; 4. Back-translation; 5. Composition of an expert committee.

These recommendations ${ }^{(5-6)}$ are for translation and cultural adaptation of research instruments. In 
this article, the adopted procedures varied because the translation and cultural adaptation were based on a PAHO document and not on a research instrument. Therefore, the pre-test application phase was not performed for psychometric evaluation and the phase of content evaluation by the expert committee closed the process.

The process of translation and cross-cultural adaptation requires a method for achieving equivalence between the source language and the target language. For instruments and documents used by cultures other than that of the source language, the ideal is not only the language translation, but a cultural adaptation to maintain the instrument content validity in different cultures $^{(7-8)}$. This situation demands planning before starting the process ${ }^{(8)}$.

This process of translation and adaptation was performed from March 2014 to March 2015 in the south of Brazil. The first phase involved requesting permission to translate and use the reference document named Marco Regional de competencias esenciales en salud pública para los recursos humanos en salud de la región de las Américas (Regional Framework of Core Competencies in Public Health for Health Human Resources in the Region of Americas) to its first author and to the Pan American Health Organization, the director institution of the collective construction of the document by specialists.

The second phase was the initial translation of the original Spanish version of the document into Portuguese. It was performed by three qualified independent translators, named T1, T2 and T3, who met the following inclusion criteria: proficiency in Spanish, experience in Spanish speaking countries, and domain of the Portuguese language. The initial contact with these translators was by e-mail and, after accepting to participate in the translation, an original version of the document was sent to them.

This phase involved participation of the three translators. The first translator (T1) was a nurse with stricto sensu training (equivalent to specialization), doctorate level in Public Health in a Spanish-speaking country, fluent in the language, with knowledge on the specific terms of the document, and aware of the study objectives. The second translator (T2) was a nurse born in Spain and fluent in Portuguese. The third translator (T3) was a Spanish language specialist, native of a Spanish-speaking country, and working on translation of materials from Spanish into Portuguese. The second and third translators were unaware of the study objectives in order to perceive interpretation errors and ambiguities in the versions translated by them.

The third phase of the study comprised the synthesis of translations and consensus. The researcher produced a synthesis of the three versions translated from Spanish to Portuguese, which were analyzed individually to identify differences between translations. The translated versions were forwarded to translators by email with divergences highlighted for comparisons between their translation and the other translated versions with the original document.

In the fourth phase, back translation or translation back into Spanish, the first translator (T1R) of the Portuguese version for Spanish was an expert in Spanish, professionally acting as a translator and interpreter of the language, and native of a Spanish speaking Latin American country. The second translator (T2R) had a degree in Languages (emphasis in Spanish), worked as a teacher and translator of the Spanish language, and was also native of a Spanish speaking Latin American country.

The original version of the document was compared to the back-translated version to check the trustworthiness of the document in translation and cultural adaptation. A web conference was held with this purpose, because a meeting face-to-face was difficult considering that translators were in different places from researchers. A new version in Spanish and the definitive version in Portuguese (P3) were obtained as a result of this phase.

The fifth phase comprised the cultural adaptation, content evaluation and analysis of cross-cultural equivalence. For the process, was formed a committee including two teaching nurses from the collective health area, a dentist and a physician acting in basic health care management in the studied municipality, and a teacher of the undergraduate course in languages (emphasis on Spanish), all of which with mastery of the Spanish language.

Members of the expert committee were selected according to the inclusion criteria: mastery of the Spanish language; active health professional working in teaching, research or practice of collective health management; or a professional of the studied language. The final version in Portuguese was defined in this phase based on the absence of divergences on cultural adaptation reported by the expert committee members.

The study was approved by the Committee of Ethics in Research with Human beings - (CEP - Comitê de Ética em Pesquisa) of a Brazilian public university under CAAE number 36031414.0.0000.0102 and number 832.463. 


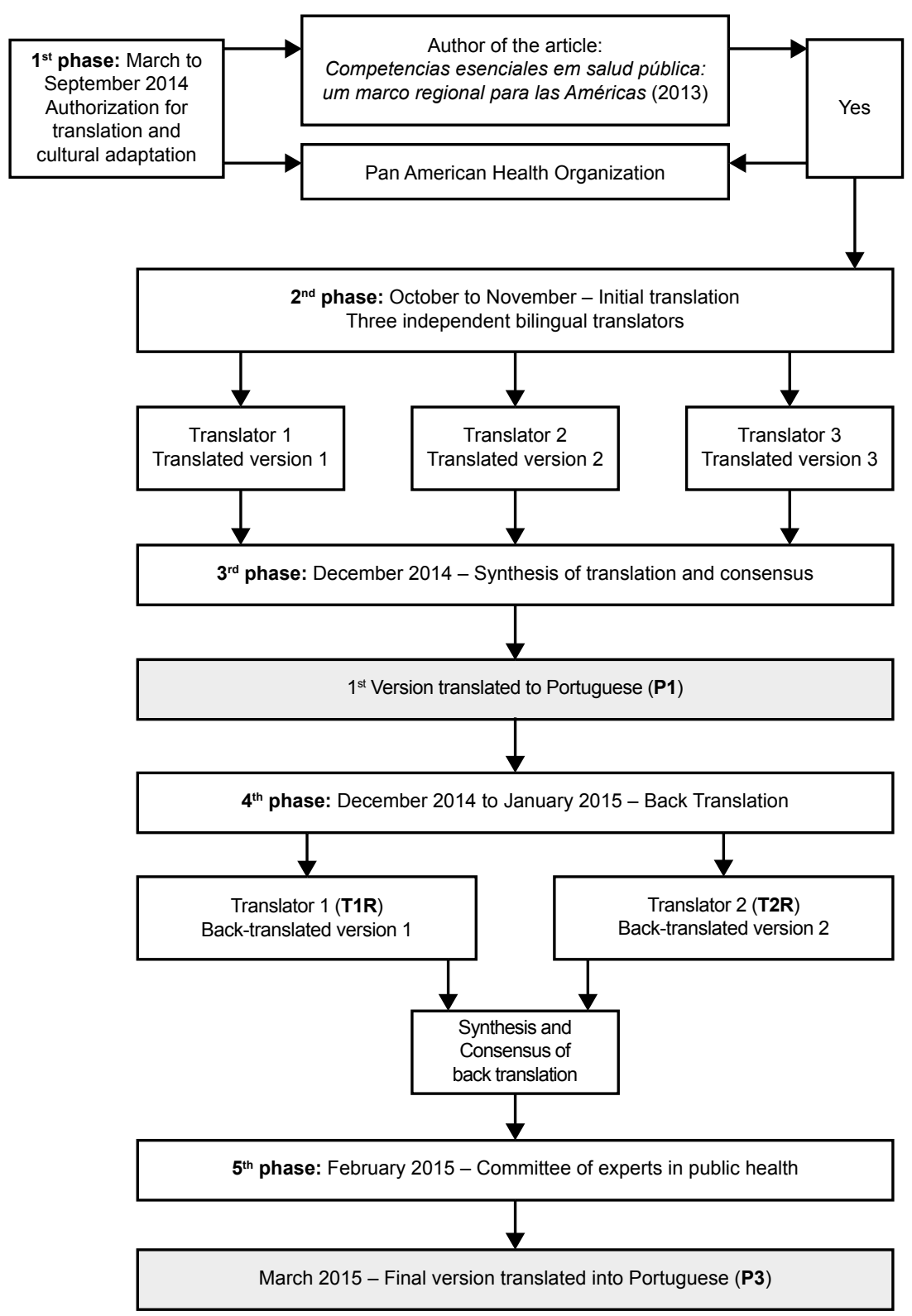

Figure 1 - Schematic representation of the methodological procedure and chronology for the translation and crosscultural adaptation of the Marco Regional de competencias esenciales em salud publica para los recursos humanos em La salud de la region de las Américas (Regional Framework of Core Competencies in Public Health for Health Human Resources in the Region of Americas).

\section{Results}

In the translation of the names of the six domains, there was no translation difference in $66.7 \%$ ( $\mathrm{N}=$ $4)$, and in $33.3 \%(N=2)$ there were divergences in domain one and domain four, which were resolved with discussion between translators and the researcher. Figure 2 presents the results of the translation and cultural adaptation of the name and description of each domain of the MRCESP after performing the five methodological phases.

In all domains, were found differences in the translation of the competency description, but the majority (above $80 \%$ ) obtained consensus in this same round, and the same happened with the words pointed as divergent.
Terms or words with the same translation among translators were not presented at the consensus meeting. After reaching consensus about the terms with differences from the initial translation, was obtained the first version translated into Portuguese. This version was sent to the back-translation and there were no significant divergences between the translation of the back-translated version in Portuguese, and the document original version in Spanish. The first Portuguese version was submitted to the expert committee for cultural adaptation and analysis of semantic, cultural, idiomatic and conceptual equivalence of the translated document, which resulted in minor changes. Thus, after the committee of experts, was obtained the final version of the translated document. 


\begin{tabular}{|c|c|}
\hline $\begin{array}{c}\text { Original and final version } \\
\text { of the Domain Name }\end{array}$ & Original and final version of the Domain Description \\
\hline $\begin{array}{l}\text { First domain: Análisis de } \\
\text { situacion de salud }\end{array}$ & $\begin{array}{l}\text { Implica la evaluación de la situación de salud poblacional y sus tendencias en función Del estudio de sus determinantes } \\
\text { para la toma de decisiones y la definición de políticas públicas de salud }\end{array}$ \\
\hline $\begin{array}{l}\text { Análise da situação de } \\
\text { saúde (Analysis of the } \\
\text { health situation) }\end{array}$ & $\begin{array}{l}\text { Implica na avaliação da situação de saúde da população e suas tendências em função do estudo de seus determinantes } \\
\text { para a tomada de decisões e definição de políticas públicas de saúde essenciais na análise de situação de saúde (It } \\
\text { implies on the evaluation of the health situation of the population and its trends in function of the study of its determinants } \\
\text { for decision making and definition of core public health policies in the analysis of the health situation). }\end{array}$ \\
\hline $\begin{array}{l}\text { Vigilancia y control de } \\
\text { riesgos y danos }\end{array}$ & $\begin{array}{l}\text { Se refiere al escrutinio continuo de todos los aspectos de la ocurrencia y propagación de riesgos y daños para la salud } \\
\text { que son pertinentes para su control efectivo en la población. Es la capacidad para llevar a cabo la investigación y vigilancia } \\
\text { de brotes epidémicos y los modelos de presentación de enfermedades transmisibles y no transmisibles, factores de } \\
\text { comportamiento, accidentes y exposición a sustancias tóxicas o agentes ambientales perjudiciales para la salud }\end{array}$ \\
\hline $\begin{array}{l}\text { Vigilância e controle } \\
\text { de riscos e danos } \\
\text { (Surveillance and control of } \\
\text { risks and threats) }\end{array}$ & $\begin{array}{l}\text { Faz referência ao escrutínio contínuo de todos os aspectos da ocorrência e propagação de riscos e danos para a saúde } \\
\text { e que são pertinentes para o seu efetivo controle na população. É a capacidade para realizar a pesquisa e a vigilância } \\
\text { do surgimento de epidemias, e os modelos de apresentação de doenças transmissíveis e não transmissíveis, fatores de } \\
\text { comportamento, acidentes e exposição a substâncias tóxicas ou agentes ambientais prejudiciais para a saúde (It refers } \\
\text { to the continuous scrutiny of all aspects of the occurrence and spread of risks and damages to health that are relevant to } \\
\text { their effective control in the population. It is the ability to conduct research and surveillance of the outbreak of epidemics, } \\
\text { and presentation models of communicable and noncommunicable diseases, behavioral factors, accidents and exposure } \\
\text { to toxic substances or environmental agents harmful to health). }\end{array}$ \\
\hline $\begin{array}{l}\text { Promoción de La salud y } \\
\text { participación social }\end{array}$ & $\begin{array}{l}\text { La Promoción de la Salud se define como el proceso político y social que abarca no solamente las acciones dirigidas } \\
\text { directamente a fortalecer las habilidades y las } \\
\text { capacidades de los individuos, sino también las dirigidas a modificar las condiciones sociales, ambientales y económicas } \\
\text { que impactan la salud. Es el proceso que permite a las personas incrementar su control sobre los determinantes de la salud } \\
\text { y em consecuencia, mejorarla. Utiliza la educación para la salud y la participación social como herramientas de cambio }\end{array}$ \\
\hline $\begin{array}{l}\text { Promoção da saúde e } \\
\text { participação social (Health } \\
\text { promotion and social } \\
\text { participation) }\end{array}$ & $\begin{array}{l}\text { A promoção da saúde se define como o processo político e social que envolve não somente as ações dirigidas diretamente } \\
\text { a fortalecer as habilidades e as capacidades dos indivíduos, como também as dirigidas a modificar as condições sociais, } \\
\text { ambientais e econômicas que impactam sobre a saúde. Consiste no processo que permite as pessoas incrementar } \\
\text { seu controle sobre os determinantes da saúde e em consequência melhorá-la. Utiliza a educação para a saúde e } \\
\text { a participação social como ferramenta de mudança (Health promotion is defined as the political and social process } \\
\text { involving not only actions directed directly at strengthening individuals' abilities and capacities, but also those aimed at } \\
\text { changing the social, environmental and economic conditions that impact on health. It consists on the process that allows } \\
\text { people to increase their control over health determinants and, consequently, to improve health. It uses education for } \\
\text { health and social participation as a tool for change). }\end{array}$ \\
\hline $\begin{array}{l}\text { Políticas, planificación, } \\
\text { regulacón y control }\end{array}$ & $\begin{array}{l}\text { Todo sistema de salud rige su gestión de acuerdo a las políticas, planes de salud y regulaciones acordadas. Los que } \\
\text { trabajan en el sector de la salud deben tener La capacidad para la gestión en el marco reglamentario de protección y } \\
\text { fiscalización en salud pública y para la cooperación internacional. Deben además tener la capacidad de generación de } \\
\text { nuevas leyes y reglamentos para el desarrollo de entornos saludables y La protección de los ciudadanos }\end{array}$ \\
\hline $\begin{array}{l}\text { Políticas, planificação, } \\
\text { regulação e controle } \\
\text { (Policy, planning, } \\
\text { regulation and control) }\end{array}$ & $\begin{array}{l}\text { Todo o sistema de saúde rege sua gestão de acordo com as políticas, planos de saúde regulatórios e regulações } \\
\text { acordadas. Os que trabalham no setor de saúde devem ter a capacidade de gestão no marco regulatório de proteção e } \\
\text { fiscalização na saúde pública e para a cooperação internacional. Devem também, ter a capacidade de gerar novas leis } \\
\text { e regulamentos para o desenvolvimento de entornos saudáveis e a proteção dos cidadãos (The entire health system } \\
\text { governs its management according to the policies, regulatory health plans and agreed regulations. Those working in the } \\
\text { health sector must have the management capacity in the regulatory framework of protection and enforcement in public } \\
\text { health and for international cooperation. They must also have the capacity to generate new laws and regulations for the } \\
\text { development of healthy environments and the protection of citizens). }\end{array}$ \\
\hline $\begin{array}{l}\text { Equidad em El accesso, } \\
\text { y calidad em los servicios } \\
\text { individuales y colectivos }\end{array}$ & $\begin{array}{l}\text { Una de las condiciones esenciales en la práctica de la Salud Pública es garantizar El acceso a los servicios, los cuales } \\
\text { deben ser otorgados universalmente sin ningún tipo de barreras, promoviendo la calidad y seguridad en su provisión y } \\
\text { desde un enfoque multisectorial para la solución de las inequidades en la atención de salud a la población. }\end{array}$ \\
\hline $\begin{array}{l}\text { Equidade ao acesso e } \\
\text { qualidade nos serviços } \\
\text { individuais e coletivos } \\
\text { (Equitable access and } \\
\text { quality of individual and } \\
\text { public health services) }\end{array}$ & $\begin{array}{l}\text { Uma das condições essenciais na prática de saúde pública é garantir acesso aos serviços, os quais devem ser dispensados } \\
\text { universalmente sem nenhum tipo de barreira, promovendo a qualidade e segurança na provisão e no enfoque multisetorial } \\
\text { para a solução das iniquidades na atenção à saúde da população (One of the essential conditions for public health practice } \\
\text { is the guarantee of universal access to services provided without any kind of barrier, promoting quality and security in the } \\
\text { provision and multisectoral approach for solving inequities in the care of the population's health). }\end{array}$ \\
\hline $\begin{array}{l}\text { Salud internacional y salud } \\
\text { global }\end{array}$ & $\begin{array}{l}\text { Es el enfoque transdisciplinario que aborda la salud desde la perspectiva del derecho universal a la salud y el bienestar } \\
\text { social. En un mundo globalizado e interconectado se requieren abordajes globales con implicaciones locales que } \\
\text { consideren los determinantes sociales de la salud y que con equidad, ética, y respeto por los derechos humanos, se } \\
\text { avance en soluciones transnacionales, regionales y globales que mejoren la salud de todos los ciudadanos del mundo. } \\
\text { Utiliza como herramientas las relaciones entre las autoridades sanitarias nacionales, a través la diplomacia en salud y } \\
\text { la cooperación técnica }\end{array}$ \\
\hline $\begin{array}{l}\text { Saúde Internacional e } \\
\text { saúde global (International } \\
\text { and global health) }\end{array}$ & $\begin{array}{l}\text { É o enfoque transdisciplinar que aborda a saúde desde a perspectiva do direito universal à saúde e o bem-estar social. } \\
\text { Num mundo globalizado e interconectado se requerem abordagens globais com implicações locais que considerem } \\
\text { os determinantes sociais da saúde e que com equidade, ética e respeito pelos direitos humanos, desenvolva soluções } \\
\text { transnacionais, regionais e globais que melhorem a saúde de todos os cidadãos do mundo. Utiliza a ferramenta das } \\
\text { relações entre as autoridades sanitárias nacionais, através da diplomacia na área da saúde e da cooperação técnica } \\
\text { (It is the interdisciplinary approach that addresses health from the perspective of the universal right to health and social } \\
\text { welfare. In a globalized and interconnected world, are required global approaches with local impact that consider the } \\
\text { social determinants of health, and which, with equity, ethics and respect for human rights, develop transnational, regional } \\
\text { and global solutions that improve the health of all the citizens of the world. It uses the tool of relations between national } \\
\text { health authorities through health diplomacy and technical cooperation). }\end{array}$ \\
\hline
\end{tabular}

Figure 2 - Translation and cultural adaptation of the name and description of domains of core competencies for human resources in public health. Brazil, 2016 


\section{Discussion}

Despite the suggestions of core competencies for Latin America, in the process of translation and adaptation to the Brazilian context it was more difficult to reach consensus in the initial translation performed by three independent translators. The expert committee acted to review the versions and carry out the cultural adaptation.

The first domain, Análise da Situação de Saúde (Health Situation Analysis), describes the competencies required from public health professionals for this analysis. It can be a support instrument for decision making and health action planning by setting priorities and building prospective scenarios that consider the evaluation of health actions, programs and policies ${ }^{(8)}$.

The competencies of the second domain, Vigilância e Controle de Riscos e Danos (Vigilance and Control of Risks and Threats), are important for public health professionals. Socio-environmental vulnerability is a result of social processes and environmental changes, a combination of difficulties in conditions of work, income, health and education, and also related to the lack of safe and healthy housing, sanitation, making certain population groups, the poorest in particular, vulnerable to disasters ${ }^{(9)}$.

In Brazil, there have been some achievements with health surveillance actions, namely the systematic and regular use of research on behavioral risk factors, such as Vigitel, to detect changes in prevalence rates of behaviors and health risks; the universal notification of significant events as the case of interpersonal violence; the use of administrative data such as emergency and hospital data and to track injuries; and the techniques of linkage, and capture and recapture for the evaluation of information system processes ${ }^{(10)}$.

The competencies of the third domain, Promoção da Saúde e Participação Social (Health Promotion and Social Participation), are strengthened with the consensus on the importance of inserting citizens in the production of care. Competent professionals in this scope can broaden their role by contributing assertively to the development of health system reforms in order to promote citizenship projects and participation in decision-making and delineation of collective goals ${ }^{(11)}$.

Health and education policies, when pointing guidelines for the training and performance of health professionals, take the promotion of health into consideration. This focus still persists in health services, although during operationalization and in response to demands there is greater concern with addressing the problem than with health promotion.
The fourth domain is called Políticas, Planejamento, Regulação e Controle (Policy, Planning, Regulation and Control). It requires that professionals have competencies focused on knowledge about the local health situation for implementing measures based on the population health needs. The use of rational planning in the epidemiological logic contributes to directing the formulation and evaluation of health policies ${ }^{(12)}$.

The fifth domain is entitled Equidade ao Acesso e Qualidade nos Serviços Individuais e Coletivos (Equitable Access and Quality of Individual and Public Health Services). The development and acquisition of its competencies is perceived as an impact factor to guarantee universal access to health that is achieved by removing barriers to the use of integral health services equitably. Therefore, human resources have a central role, despite the great difficulties still perceived on this theme in primary health care ${ }^{(13)}$.

The competencies of the sixth domain, Saúde Internacional e Global (International and Global Health) are as important as current, and in times of globalization, it is essential that public health professionals have such competencies. The term global health goes beyond the existing divide between the rich and poor, the developed and in development, and the national boundary lines ${ }^{(14-15)}$. This domain is focused on the cultural, social, economic and political possibilities outlining the world scope ${ }^{(14)}$.

For their solution, global health problems require international cooperation to address issues related to old causes of death in Brazil that are still priority problems in other countries, such as malnutrition and child mortality. In the present and future, collaboration between countries demands the joint overcoming of challenges to advance in the care for violence and chronic-degenerative diseases, such as cardiovascular disease, lung disease, cancer and diabetes. Global health also includes preventive issues addressed to different populations, and has the greater objective of equity and access to health care for all(15).

Regarding the debate on the construction of competency models for public health, the movement of the Galway Consensus Conference took place in 2008. It showed an international concern with the theme in this area, facing a new health scenario and the demand for professionals prepared for $\mathrm{it}^{(4)}$. The aim of this event was the promotion of dialogue and knowledge exchange among international scholars on areas of competency, norms and ways of ensuring quality in the preparation of professionals and specialists in health education for the practice of health promotion ${ }^{(16)}$.

The identification of these competencies aims at the development of the workforce because it is a 
starting point and reinforcement for health organizations understanding the need for this type of investment for improving health care provision ${ }^{(1)}$. It is an institutional role to solve the population health problems efficiently and effectively, with the necessary requisites for all professionals who practice in public health, regardless of their field of activity or activity developed(2).

More specifically, core competencies can be used for assessment of public health personnel performance in order to identify needs for training, development and planning for continuing education, and elaboration of job description. Therefore, organizations providing public health services can interpret and adapt core competencies for meeting specific organizational needs $^{(2)}$.

\section{Final considerations}

The document named Marco Regional de Competencias Esenciales em Salud Pública para los Recursos Humanos en Salud de la Región de las Américas (Regional Framework of Core Competencies in Public Health for Health Human Resources in the Region of Americas) was translated and adapted to the Brazilian context following international guidelines procedures. This study allows the use of skills translated and adapted to the Brazilian context as a reference for what is expected from human resources working in public health care in Brazil, because they define knowledge, skills and attitudes related to this area.

The potential for application and use of this translated document for knowledge production in the various dimensions of professional practice in collective/ public health in Brazil, and to collaborate for the improvement of health care provided to the population are noteworthy. Future research on the use of this competency framework in collective/public health care is recommended.

\section{References}

1. National Collaborating Centre for Determinants of Health. Core Competencies for Public Health in Canada: An assessment and comparison of determinants of health content [Internet]. Antigonish, NS: National Collaborating Centre for Determinants of Health, St. Francis Xavier University, 2012. [cited Sep 20 2015]. Available from: http://www.phans.ca/cmsAdmin/uploads/Core competencies_EN_121001.pdf

2. Organización Panamericana de la Salud. Competencias esenciales em salud pública: um marco regional para las Américas [Internet]. Washington, DC: OPS; 2013. [Acceso 7 feb 2015]. Disponíble en: http:// www.observatoriorh.org/sites/default/files/webfiles/ fulltext/2014/competencias_sp.pdf

3. Conjero JS. Competencias esenciales en salud pública: un marco regional para las Américas. Rev Panam Salud Pública. [Internet]. 2013;34(1):47-53. [Acceso 17 ene 2014]. Disponíble en: http://www.scielosp.org/scielo. php?script=sci_arttext\&pid=S1020-49892013000700007 4. Fragelli TBO, Shimizu HE. Competências profissionais em Saúde Pública: conceitos, origens, abordagens e aplicações. Rev Bras Enferm. [Internet] 2016 [citado 2 jan 2017];65(4):667-74. Disponível em: http://www. scielo.br/scielo.php?script =sci_arttext\&pid=S003471672012000400017\&lng=e. http://dx.doi.org/10.1590/ S0034-71672012000400017.

5. Guillemin F, Bombardier C, Beaton D. Crosscultural adaptation of health-related quality of life measures: literature review and proposed guidelines. J Clin Epidemiol. 1993;46(12):1417-32.

6. Beaton D, Bombardier C, Guillemin F, Ferraz MB. Recommendations for the cross-cultural adaptation of health status measures. [Internet]. Califórnia: American Academy of Orthopaedic Surgeons and Institute for Work \& Health; 2007. [cited March 3 2014]. Available from: http://www.dash.iwh.on.ca

7. Lessa PRA, Ribeiro SG, Aquino OS, Almeida PC, Pinheiro AKB. Validation of the Adherence Determinants Questionnaire scale among women with breast and cervical cancer. Rev. Latino-Am. Enfermagem. 2015;23(5):971-78. doi: http://dx.doi. org/10.1590/0104-1169.0222.2638

8. Mota FRN, Victor JF, Silva MJ, Bessa MEP, Amorim VL, Cavalcante MLSN, et al . Cross-cultural adaptation of the Caregiver Reaction Assessment for use in Brazil with informal caregivers of the elderly. Rev Esc Enferm USP. 2015;49( 3 ): 424-431. doi: http://dx.doi.org/10.1590/ S0080-623420150000300010

9. Ministério da Saúde (BR). Secretaria-Executiva. Secretaria de Vigilância em Saúde. Glossário temático: promoção da saúde, 2012 [Internet]. [citado 12 ago 2015]. Disponível em: http://bvsms.saude.gov.br/bvs/ publicacoes/glossario_promocao_saude_1ed.pdf

10. Macinko J. Advances in Brazilian public health surveillance. Ciênc Saúde Coletiva. [Internet]. 2015 Mar [cited Nov 212016 ]; 20(3):628-9. Available from: http://www.scielosp.org/scielo.php?script=sci_ arttext\&pid $=$ S1413-81232015000300628\&Ing =en. http://dx.doi.org/10.1590/1413-81232015203. 20092014

11. Serapioni M. Os desafios da participação e da cidadania nos sistemas de saúde. Ciênc Saúde Coletiva. [Internet]. 2014;19(12):4829-39. [citado 2 maio 2015]. Disponível em: http://www.scielo.br/pdf/csc/v19n12/1413-8123csc-19-12-04829.pdf 
12. Oliveira JS, Nery AA, Vilela ABA, Santos CS, Bispo KCA.The management tools: The tools of the social control. Rev Enferm UFPE on line. [Internet]. 2013;7(1):192-8. [cited Sep 20 2015]. Available from: http://www.revista.ufpe.br/revistaenfermagem/index. php/revista/article/view/3284/pdf_1881

13. Cassiani SHDB. Strategy for universal access to health and universal health coverage and the contribution of the International Nursing Networks. [Editorial]. Rev Latino-am Enfermagem. [Internet]. 2014;22(6):891-2. [cited Sep 20 2015]. Available from: http://www.scielo.br/scielo.php?script=sci_arttext\&pid =S0104-11692014000600891

14. Fortes PAC, Ribeiro H. Saúde Global em tempos de globalização. Saúde Soc. [Internet]. 2014;239(2):366-75. [citado 20 set 2015]. Disponível em: http://www.scielo. br/pdf/sausoc/v23n2/0104-1290-sausoc-23-2-0366.pdf 15. Instituto Nacional de Operações Espaciais. Saúde global para um planeta sob pressão. Transição para a sustentabilidade: desafios interligados e soluções [Internet]. Conferência Internacional Planet under Pressure. New Knowledge Towards Solutions; 2012. [citado 29 fev 2014]. Disponível em: http://www.inpe. br/igbp/arquivos/Health_FINAL_LR-portugues.pdf

16. Allegrante JP. Domains of Core Competency, Standards, and Quality Assurance for Building Global Capacity in Health Promotion: The Galway Consensus Conference Statement. doi: Health Educ Behav. 2009 Jun;36(3):476-82. doi: 10.1177/1090198109333950. Epub 2009 May 15.

Copyright $\odot 2017$ Revista Latino-Americana de Enfermagem This is an Open Access article distributed under the terms of the Creative Commons (CC BY).

This license lets others distribute, remix, tweak, and build upon your work, even commercially, as long as they credit you for the original creation. This is the most accommodating of licenses offered. Recommended for maximum dissemination and use of licensed materials. 